\title{
Bur open Coronary and mortality risk of novel oral antithrombotic agents: a meta-analysis of large randomised trials
}

To cite: Mak K-H. Coronary and mortality risk of novel oral antithrombotic agents: a meta-analysis of large randomised trials. BMJ Open 2012;2:e001592. doi:10.1136/ bmjopen-2012-001592

- Prepublication history and additional material for this paper are available online. To view these files please visit the journal online (http://dx.doi.org/10.1136/ bmjopen-2012-001592).

Received 31 May 2012 Accepted 30 August 2012

This final article is available for use under the terms of the Creative Commons Attribution Non-Commercial 2.0 Licence; see http://bmjopen.bmj.com

Mak Heart Clinic, 6 Napier Road, \#08-13, Singapore, Singapore, 258499

Correspondence to Koon-Hou Mak; makheart@ gmail.com

\section{ABSTRACT}

Objective: Oral direct thrombin and anti-Xa inhibitors have been shown to be efficacious in the prevention and treatment of venous thromboembolism, and prevention of embolic events in atrial fibrillation. Recent studies showed that dabigatran may be associated with increased rates of myocardial infarction (MI). Coronary risk for the other agents was unclear. The aim of the study is to determine the coronary risk among four novel antithrombotic agents.

Design: Mixed treatment comparison meta-analysis. Data sources and study selection: Randomised controlled trials (RCTs) on ximelagatran, dabigatran, rivaroxaban and apixaban were obtained from PubMed search (February 2012) and major scientific meeting in 2011. The random-effects model was used to evaluate the effect of these agents on MI or acute coronary syndrome (MI/ACS), major bleeding complication and all-cause mortality.

Results: From 28 RCTs ( $n=138$ 948), the risk for MI/ACS was higher for dabigatran (OR $1.30 ; 95 \% \mathrm{Cl}$ 1.04 to $1.63 ; p=0.021$ ) but lower for rivaroxaban (OR $0.78 ; 95 \% \mathrm{Cl} 0.69$ to $0.89 ; \mathrm{p}<0.001$ ). Ximelagatran showed a higher risk for MI/ACS, which was not statistically significant, while apixaban demonstrated a non-significant lower likelihood. Among the RCTs for MI/ACS among the four agents, only those pertaining to ximelagatran showed heterogeneity. Major bleeding complication rates varied considerably among different agents. Importantly, these agents were associated with a lower all-cause mortality, without heterogeneity among the studies.

Conclusions: The risk for coronary events was significantly higher for dabigatran but not significantly higher for ximelagatran. Conversely, this risk was lower among anti-Xa inhibitors. All-cause mortality was lower among those receiving novel antithrombotic agents. This information may be useful in selecting agents for specific subsets of patients requiring anticoagulation.

\section{INTRODUCTION}

Several cardiovascular conditions are related to thromboembolism. In the past few decades, focus has been on the development of antiplatelet agents because of the perceived pre-

\section{ARTICLE SUMMARY}

Article focus

- Novel oral anticoagulants have been efficacious in preventing thrombotic complications among patients with atrial fibrillation and venous thromboembolism.

- There is concern regarding coronary risks.

- The study aims to ascertain this risk among the novel antithrombotic agents.

Key messages

- While oral direct thrombin inhibitors may be associated with a higher coronary risk, this risk may not be present for oral factor $X a$ inhibitors.

- Individual coronary risk may influence the choice of oral anticoagulant.

Strengths and limitations of this study

- This is a large meta-analysis, and the finding was consistent with previous meta-analysis evaluating the coronary risk of dabigatran.

- Similar to any meta-analysis, the results are hypothesis generating for comparing direct groups of oral anticoagulants.

eminent role played by thrombocytes in arterial, particularly coronary, thrombosis. For several years, advancement in anticoagulation has been limited to refining the heparin complex and parenteral direct thrombin inhibitors such as hirudin and bivalrudin. Indeed, warfarin was the sole oral anticoagulant for the past 60 years. Novel agents have been designed to act against factor Xa and thrombin recently. Their efficacy has been shown in preventing venous thromboembolism (VTE) among patients undergoing hip or knee surgery and embolic events among those with atrial fibrillation, and treating those with VTE or acute coronary syndromes (ACS). Amidst the enthusiasm of favourable results, higher rates of myocardial infarction (MI) among patients receiving dabigatran initially reported in the Randomised Evaluation of Long-term Anticoagulant Therapy (RE-LY) trial $^{1}$ have generated concern regarding the overall 
effectiveness of this agent. Although subsequent re-analysis of the data following identification of another four clinical and 28 silent MI showed that the increase was not statistically significant (HR 1.28; 95\% CI 0.98 to $1.67 ; \mathrm{p}=0.07$ ). ${ }^{2}$ However, a recent meta-analysis showed that the risk of coronary events was increased with the use of dabigatran, even after including the additional events. ${ }^{3}$

To date, there have been four novel oral anticoagulants that have been evaluated in large clinical trials for thromboembolic conditions: ximelagatran (Exanta; Astra-Zeneca, London, UK), dabigatran (Pradaxa; Boehringer Ingelheim, Ingelheim, Germany), rivaroxaban (Xarelto; Bayer, Leverkusen, Germany) and apixaban (Eliquis; Bristol-Myers Squibb, New York City, New York, USA). The first two agents are direct thrombin inhibitors while the latter two act against factor Xa. With different mechanism of action, the aim of the study is to review the risk of acute coronary events among these agents. Taken together, they may provide a better ascertainment of the coronary risk between direct thrombin inhibitors and anti-Xa agents.

\section{METHODS}

Using the PubMed, a search was conducted on 18 February 2012 with the terms, ximelagatran or dabigatran or rivaroxaban or apixaban, and was limited to clinical trials. Additional records were identified from abstracts presented at major scientific meetings in 2011: namely, the 60th Annual Scientific Session of the American College of Cardiology (http://www.abstractsonline.com/ plan/AdvancedSearch.aspx), the XXIII Congress of the International Society of Thrombosis and Haemostasis (http://onlinelibrary.wiley.com/doi/10.1111/jth.2011.9. issue-s2/issuetoc) and the American Heart Association Scientific Session 2011 (http://circ.ahajournals.org/ content/vol124/21_MeetingAbstracts). Only studies with at least 1000 subjects were included. Manuscripts that did not report on the occurrence of acute coronary events or all-cause mortality were excluded. Various doses of the same study drug were grouped together as treatment arm as the numbers of patients and events in each of the doses were small, especially in phase II studies. The primary outcome was acute coronary events comprising either MI or ACS (unstable angina, MI or cardiac death), based on individual reports. All-cause mortality and major bleeding complication rates were secondary outcome measures. However, the definition of major bleeding complication varied among the studies.

Study quality was assessed by the Jadad scale, ${ }^{4}$ which scored up to 2 points for randomisation, 2 points for blinding and 1 point for description of withdrawals and dropouts. Points may be deducted for inappropriateness in randomisation or blinding. A score of 3 or more points suggest the trial was of high quality. Meta-analysis was performed using Comprehensive Meta-analysis V.2 (Biostat, Inc, Engelwood, New Jersey, USA). The associations between risk of each of the outcomes in the control groups (baseline risk): acute coronary events, major bleeding complications and all-cause mortality, with the corresponding OR of the use of each of the antithrombotic agents for each of the indication of use, namely VTE prophylaxis, treatment of thromboembolism, prevention of thromboembolism among those with non-valvular atrial fibrillation and ACSs, were evaluated with a linear fixed-effects meta-regression model. For studies using dissimilar agents in the control group, the random-effects model was applied instead. In the overall results, the random-effects model was used. Heterogeneity was quantified with $\mathrm{I}^{2}$ statistics. ${ }^{5}$ Publication bias was determined by Funnel plot and Egger regression test. ${ }^{6}$

\section{RESULTS}

A total of 274 abstracts were identified and reviewed. Of these, 42 full-text articles were appraised, and eventually, 28 randomised control trials (RCTs) were selected (figure 1), consisting of 138948 participants. The numbers of trials evaluating ximelagatran, dabigatran, rivaroxaban and apixaban were six, nine, seven and seven, respectively, and were sponsored by their respective pharmaceutical companies. They were conducted in the setting VTE prevention among patients undergoing hip or knee surgery (13 studies), treatment of individuals with VTE (5 studies), prevention of embolic events in patients with atrial fibrillation (6 studies) and treatment of subjects with ACSs (4 studies). Study participants were followed from about a week to 2 years. The characteristics of the trials are provided in table 1.

\section{Impact on MI/ACS}

Of the four drugs, the risk for MI/ACS was higher for dabigatran (OR 1.30; 95\% CI 1.04 to 1.63 ; $\mathrm{p}=0.021$ ) but lower for rivaroxaban (OR 0.78 ; $95 \%$ CI 0.69 to 0.89 ; $\mathrm{p}<0.001$ ) (figure 2). The other oral direct thrombin inhibitor, ximelagatran, showed a higher risk for MI/ACS, which was not statistically significant, and apixaban, a factor Xa inhibitor, demonstrated a non-statistically significant lower likelihood. Unlike trials involving dabigatran, rivaroxaban and apixaban, there was marked heterogeneity for studies evaluating ximelagatran $\left(\mathrm{I}^{2}=79.69\right.$; $\mathrm{p}=0.007$ ).

\section{Major bleeding complications}

Overall, the risk of major bleeding complications was comparable between oral direct thrombin inhibitors and warfarin (figure 3). When the trial on patients with ACS was excluded, dabigatran was associated with a reduced risk for major bleeding complications (OR 0.89; 95\% CI 8.80 to $0.999 ; \mathrm{p}=0.049)$. But there was still considerable heterogeneity among the studies $\left(\mathrm{I}^{2}=67.29 ; \mathrm{p}=0.003\right)$. Conversely, the risk for major bleeding complication was $15 \%$ higher for rivaroxaban. Again, there was marked heterogeneity because of dissimilar trial design, the heightened risk for major bleeding complication was attenuated after excluding the study on ACS (OR 1.03; 


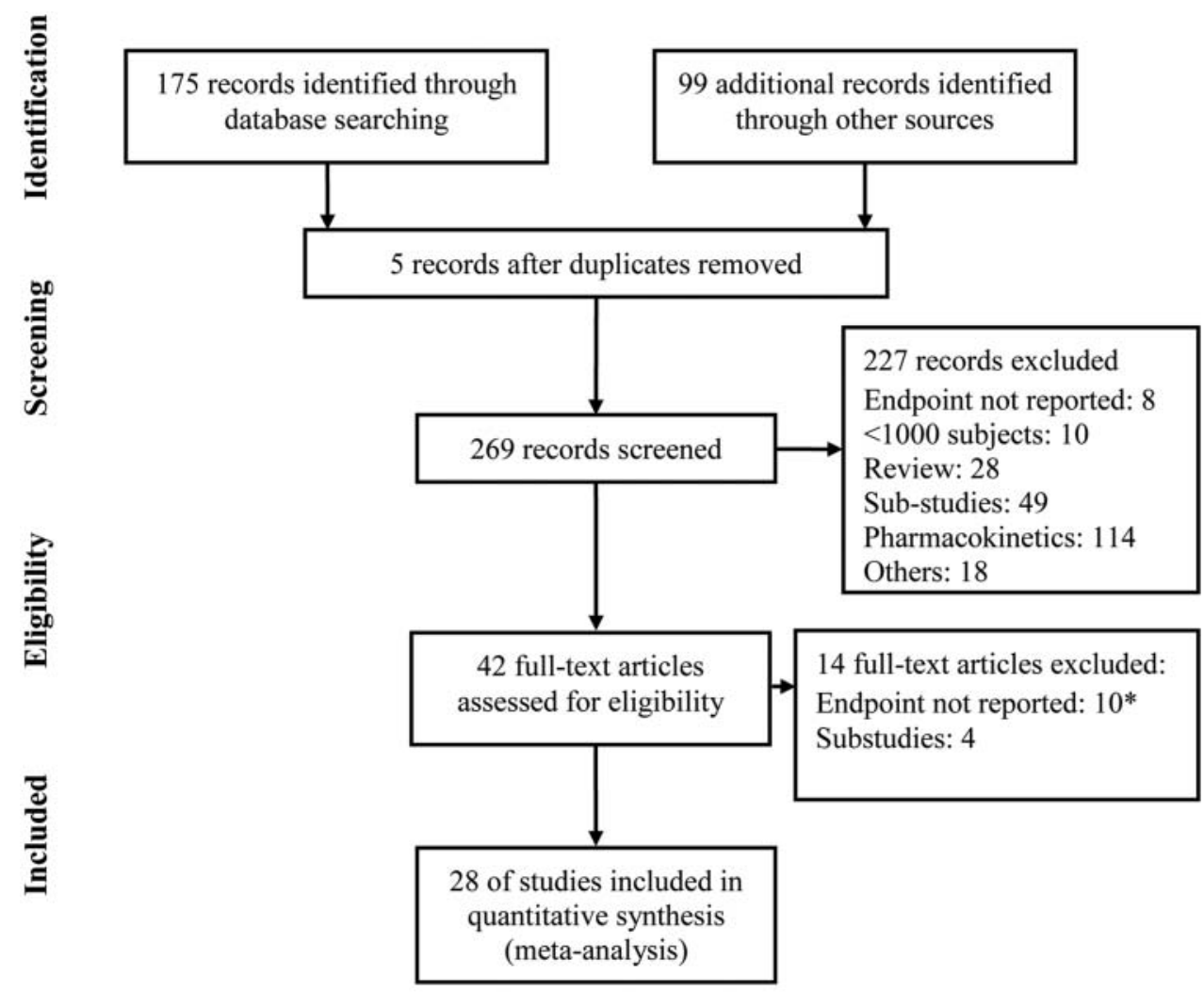

*ximelagatran 6 , dabigatran 1 , rivaroxaban, 2, apixaban, 1

Figure 1 PRISMA (Preferred reporting items for systematic reviews and meta-analyses) flow diagram of study selection.

95\% CI 0.90 to $1.19 ; \mathrm{p}=0.638)$. Test for heterogeneity became non-significant $\left(\mathrm{I}^{2}=3.32 ; \mathrm{p}=0.395\right)$. Overall, apixaban was associated with a non-statistically significant lower likelihood for major bleeding, with marked heterogeneity among trials. When the studies on ACS were excluded, the risk for major bleeding of significantly lower for apixaban (OR 0.69; $95 \%$ CI 0.61 to 0.79 ; $\mathrm{p}<0.001)$ and without significant heterogeneity $\left(\mathrm{I}^{2}=1.84\right)$. Conversely, major bleeding complications occurred more frequently among patients receiving apixaban in ACS trials (OR 2.61; 95\% CI 1.52 to 4.72; $\mathrm{p}<0.001)$ without significant heterogeneity $\left(\mathrm{I}^{2}<0.001\right)$.

\section{All-cause mortality}

Aside from ximelagatran, the use of dabigatran, rivaroxaban and apixaban was associated with the reduction in all-cause mortality (figure 4). Importantly, there was no significant heterogeneity among the trials.

Funnel plot with Engger regression test did not show evidence for publication bias for the various outcomes (figure 5 showing data only for MI/ACS). Meta-regression analysis did not show any relationship between each antithrombotic agent and individual outcome measures, except for ximelagatran with MI/ ACS $(p=0.007)$, rivaroxaban with major bleeding complication $(\mathrm{p}<0.001)$ and apixaban with major bleeding complication $(\mathrm{p}=0.004)$.

\section{DISCUSSION}

This meta-analysis showed that dabigatran was associated with increased risk for acute coronary events. Conversely, the greater likelihood for coronary events for the other oral direct thrombin inhibitor, ximelagatran, was not statistically significant. The excess risk associated with dabigatran was comparable to the findings of the earlier meta-analysis. ${ }^{3}$ Conversely, the risk for MI/ACS was lower for rivaroxaban, and a non-statistically significant reduction was observed for apixaban. Therefore, it appeared that the coronary risk differed between oral direct thrombin inhibitors and anti-Xa agents. Although the variation in the use of antiplatelet agents could have accounted for some of these differences, it was interesting to note that dabigatran was associated with a higher and rivaroxaban was associated with a lower risk for MI/ ACS in clinical studies of ACS patients. Majority of them would have been treated with at least one antiplatelet agent. Therefore, based on these findings, those with heightened coronary risk, the use of anti-Xa agents may be preferable to direct thrombin inhibitors.

While both ximelagatran and low-molecular-weight heparins were able to reduce platelet activation, thrombin generation ${ }^{35}$ and endogenous thrombin potential, ${ }^{36}$ the time reduction for endogenous thrombin potential was greater for dalteparin compared with ximelagatran. ${ }^{36}$ Conversely, rivaroxaban was superior to dalteparin in preventing thrombin generation following hip 
Table 1 Characteristics of randomised controlled trials evaluating novel antithrombotic agents in various medical conditions

\begin{tabular}{|c|c|c|c|c|c|c|c|}
\hline Study name & Study population & Primary endpoint & $\begin{array}{l}\text { Coronary } \\
\text { event }\end{array}$ & $\begin{array}{l}\text { Study drug and dose (number } \\
\text { of subjects) }\end{array}$ & $\begin{array}{l}\text { Control drug and dose } \\
\text { (number of subjects) }\end{array}$ & $\begin{array}{l}\text { Duration of } \\
\text { therapy }\end{array}$ & $\begin{array}{l}\text { Jadad } \\
\text { score }\end{array}$ \\
\hline \multicolumn{8}{|c|}{ Venous thromboembolism prophylaxis } \\
\hline EXULT $A^{7}$ & Knee surgery & VTE, death & NR & $\begin{array}{l}\text { Ximelagatran } \\
36 \text { mg twice daily }(n=629) \\
24 \text { mg twice daily }(n=614)\end{array}$ & Warfarin $(n=608)$ & $7-12$ days & 5 \\
\hline EXULT B ${ }^{8}$ & Knee surgery & VTE, death & NR & $\begin{array}{l}\text { Ximelagatran } \\
36 \text { mg twice daily }(n=982)\end{array}$ & Warfarin $(n=967)$ & $7-12$ days & 5 \\
\hline RE-NOVATE ${ }^{9}$ & Hip surgery & VTE, death & ACS & $\begin{array}{l}\text { Dabigatran } \\
150 \text { mg once daily }(n=874) \\
220 \text { mg once daily }(n=880)\end{array}$ & $\begin{array}{l}\text { Enoxaparin } \\
40 \text { mg once daily }(n=897)\end{array}$ & 28-35 days & 5 \\
\hline RE-MODEL ${ }^{10}$ & Knee surgery & VTE, death & ACS & $\begin{array}{l}\text { Dabigatran } \\
150 \text { mg once daily }(n=526) \\
220 \text { mg once daily }(n=503)\end{array}$ & $\begin{array}{l}\text { Enoxaparin } \\
40 \mathrm{mg} \text { once daily }(\mathrm{n}=512)\end{array}$ & $6-10$ days & 5 \\
\hline RE-MOBILIZE ${ }^{11}$ & Knee surgery & VTE, death & $\begin{array}{l}\text { cardiac } \\
\text { events* }\end{array}$ & $\begin{array}{l}\text { Dabigatran } \\
150 \text { mg once daily }(n=649) \\
220 \text { mg daily }(n=604)\end{array}$ & $\begin{array}{l}\text { Enoxaparin } \\
30 \text { mg twice daily }(n=643)\end{array}$ & $\begin{array}{l}14 \dagger(12-15) \\
\text { days }\end{array}$ & 5 \\
\hline RE-NOVATE $\|^{12}$ & Hip surgery & VTE, death & MI & $\begin{array}{l}\text { Dabigatran } \\
220 \text { mg once daily }(n=792)\end{array}$ & $\begin{array}{l}\text { Enoxaparin } \\
40 \mathrm{mg} \text { once daily }(\mathrm{n}=785)\end{array}$ & 28-35 days & 5 \\
\hline RECORD $1^{13}$ & Hip surgery & VTE, death & MI & $\begin{array}{l}\text { Rivaroxaban } \\
10 \text { mg daily }(n=1595)\end{array}$ & $\begin{array}{l}\text { Enoxaparin } \\
40 \text { mg daily }(n=1558)\end{array}$ & $\begin{array}{l}36 \dagger(30-42) \\
\text { days }\end{array}$ & 5 \\
\hline RECORD2 $2^{14}$ & Hip surgery & VTE, death & MI & $\begin{array}{l}\text { Rivaroxaban } \\
10 \text { mg daily }(n=1252)\end{array}$ & $\begin{array}{l}\text { Enoxaparin } \\
40 \text { mg daly }(n=1257)\end{array}$ & $30-42$ days & 5 \\
\hline RECORD3 $^{15}$ & Knee surgery & VTE, death & MI & $\begin{array}{l}\text { Rivaroxaban } \\
10 \text { mg daily }(n=1254)\end{array}$ & $\begin{array}{l}\text { Enoxaparin } \\
40 \text { mg daily }(n=1277)\end{array}$ & 13-17 days & 5 \\
\hline RECORD4 $4^{16}$ & Knee surgery & VTE, death & $\mathrm{MI}$ & $\begin{array}{l}\text { Rivaroxaban } \\
10 \text { mg daily }(n=965)\end{array}$ & $\begin{array}{l}\text { Enoxaparin } \\
30 \text { mg twice daily }(n=959)\end{array}$ & 13-17 days & 5 \\
\hline ADVANCE $1^{17}$ & Knee surgery & VTE, death & MI & $\begin{array}{l}\text { Apixaban } \\
2.5 \mathrm{mg} \text { twice daily }(\mathrm{n}=1599)\end{array}$ & $\begin{array}{l}\text { Enoxaparin } \\
30 \mathrm{mg} \text { twice daily }(\mathrm{n}=1596)\end{array}$ & $10-14$ days & 5 \\
\hline ADVANCE $2^{18}$ & Knee surgery & VTE, death & MI & $\begin{array}{l}\text { Apixaban } \\
2.5 \mathrm{mg} \text { twice daily }(n=1528)\end{array}$ & $\begin{array}{l}\text { Enoxaparin } \\
40 \text { mg daily }(n=1529)\end{array}$ & 10-14 days & 5 \\
\hline ADVANCE $3^{19}$ & Hip surgery & VTE, death & MI & $\begin{array}{l}\text { Apixaban } \\
2.5 \mathrm{mg} \text { twice daily }(\mathrm{n}=1949)\end{array}$ & $\begin{array}{l}\text { Enoxaparin } \\
40 \text { mg daily }(n=1917)\end{array}$ & 35 days & 5 \\
\hline \multicolumn{8}{|c|}{ Treatment of venous thromboembolism } \\
\hline THRIVE $^{20}$ & Acute VTE therapy & Recurrent VTE & ACS & $\begin{array}{l}\text { Ximelagatran } \\
36 \text { mg twice daily }(n=1240)\end{array}$ & $\begin{array}{l}\text { Enoxaparin followed by } \\
\text { warfarin }(n=1249)\end{array}$ & 6 months & 5 \\
\hline RE-COVER ${ }^{21}$ & VTE therapy & VTE & ACS & $\begin{array}{l}\text { Dabigatran } \\
150 \text { mg twice daily ( } n=1273)\end{array}$ & $\begin{array}{l}\text { Parenteral anticoagulation } \\
\text { then warfarn }(n=1266)\end{array}$ & 6 months & 5 \\
\hline RE-SONATE ${ }^{22}$ & Extended VTE therapy & $\begin{array}{l}\text { Recurrent VTE, related } \\
\text { death }\end{array}$ & CV events & $\begin{array}{l}\text { Dabigatarn } \\
150 \text { mg twice daily ( } n=681 \text { ) }\end{array}$ & Placebo $(n=662)$ & 6 months & $3 \ddagger$ \\
\hline REMEDY 23 & Extended VTE therapy & $\begin{array}{l}\text { Recurrent VTE, related } \\
\text { death }\end{array}$ & ACS & $\begin{array}{l}\text { Dabigatran } \\
150 \text { mg twice daily }(n=1430)\end{array}$ & Warfarin $(n=1426)$ & 6-36 months & $3 \ddagger$ \\
\hline EINSTEIN ${ }^{24}$ & $\begin{array}{l}\text { Symptomatic DVT } \\
\text { therapy }\end{array}$ & Recurrent VTE & ACS & $\begin{array}{l}\text { Rivaroxaban } \\
15 \mathrm{mg} \text { twice daily for } 3 \text { weeks, } \\
\text { then } 20 \mathrm{mg} \text { daily }(\mathrm{n}=1718)\end{array}$ & $\begin{array}{l}\text { Heparin followed by warfarin } \\
(n=1711)\end{array}$ & $3,6,12$ months & 5 \\
\hline
\end{tabular}


Table 1 Continued

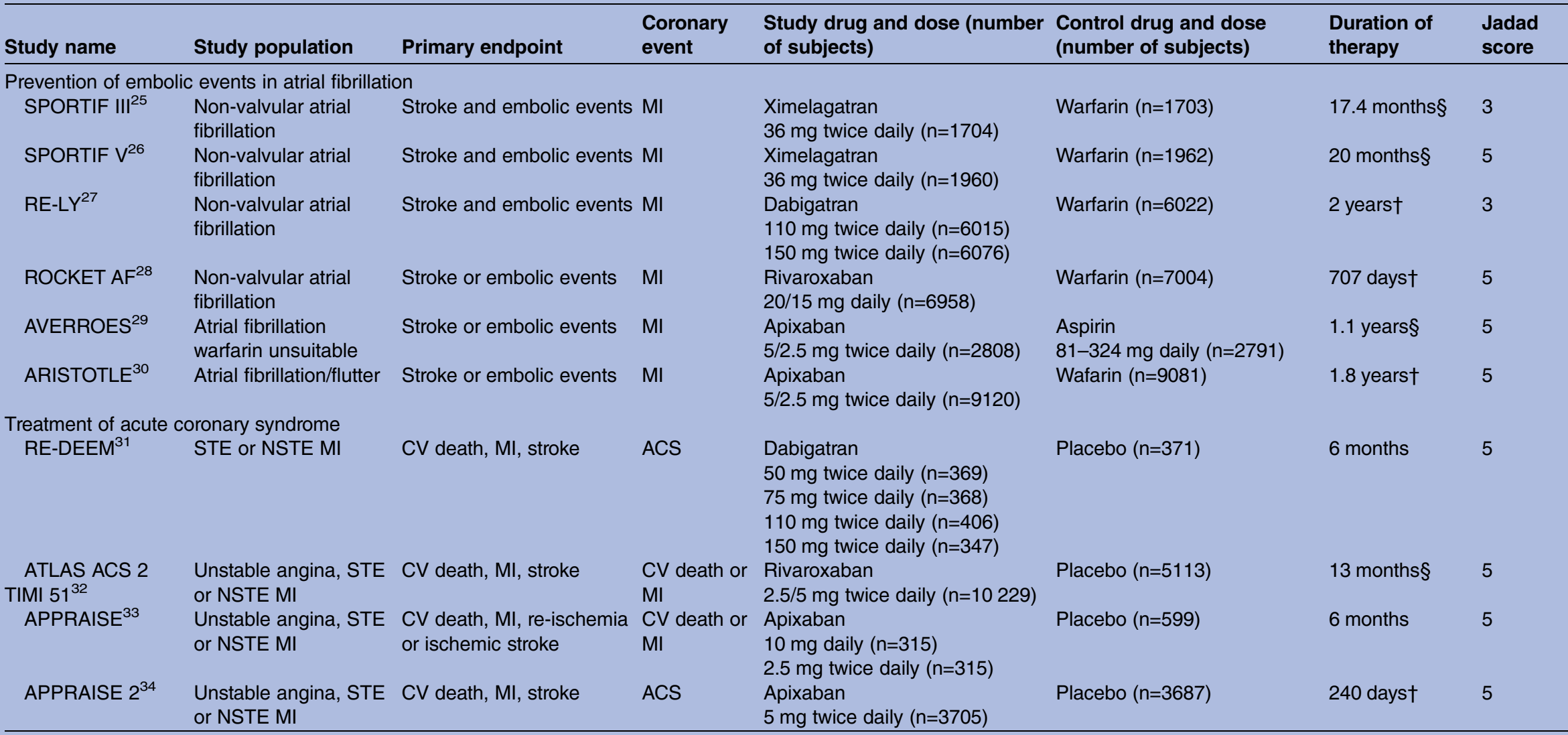

${ }^{*}$ Cardiac events, specifics were not provided but events were reviewed by a blinded independent committee.

†Median.

$\ddagger$ Limited information available.

§Mean.

VTE, venous thromboembolism; NR, not reported; ACS, acute coronary syndrome (consisting of unstable angina, myocardial infarction and cardiac death); MI, myocardial infarction; CV, cardiovascular; STE, ST-segment-elevation; NSTE, non-ST-segment-elevation

Acronyms for studies, where applicable: EXULT, Exanta Used to Lessen Thrombosis; RECORD, Regulation of Coagulation in Orthopedic Surgery to Prevent Deep Vein Thrombosis and Pulmonary Embolism; ADVANCE, Apixaban Dose Orally versus. Anticoagulant with Enoxaparin; THRIVE, the Thrombin Inhibitor in Venous Thromboembolism; SPORTIF, Stroke Prevention using an ORal Thrombin Inhibitor in atrial Fibrillation; RE-LY, Randomized Evaluation of Long-Term Anticoagulation Therapy; ROCKET AF; Rivaroxaban Once Daily Oral Direct Factor Xa Inhibition Compared with Vitamin K Antagonism for Prevention of Stroke and Embolism Trial in Atrial Fibrillation; AVERROES, Apixaban Versus Acetylsalicylic Acid to Prevent Stroke in Atrial Inhibition Compared with Vitamin K Antagonism for Prevention of Stroke and Embolism Trial in Atrial Fibrillation; AVERROES, Apixaban Versus Acetylsalicylic Acid to Prevent Stroke in Atr Fibrillation Patients Who Have Failed or Are Unsuitable for Vitamin K Antagonist Treatment; ARISTOTLE, Apixaban for Reduction in Stroke and Other Thromboembolic Events in Atrial
Fibrillation; ATLAS ACS 2-TIMI 51, Anti-Xa Therapy to Lower Cardiovascular Events in Addition to Standard Therapy in Subjects with Acute Coronary Syndrome-Thrombolysis in Myocardial

Fibrillation; ATLAS ACS 2-TIMI 51, Anti-Xa Therapy to Lower Cardiovascular Events in Addition
Infarction 51; APPRAISE, Apixaban for Prevention of Acute Ischemic and Safety Events Trial. 
Ximelagatran: Coronary Events

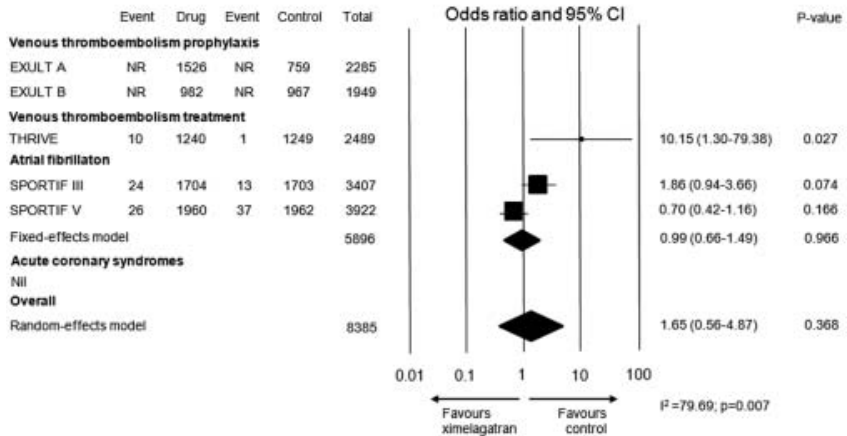

Dabigatran: Coronary Events

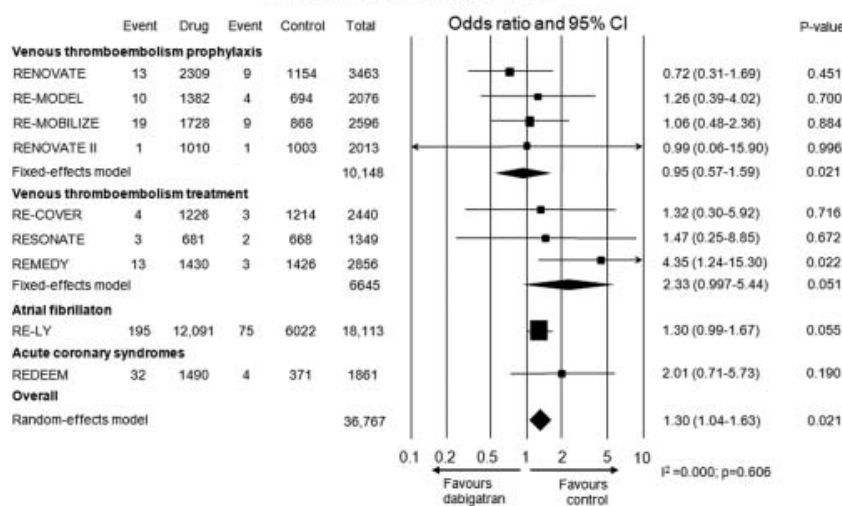

Rivaroxaban: Coronary Events

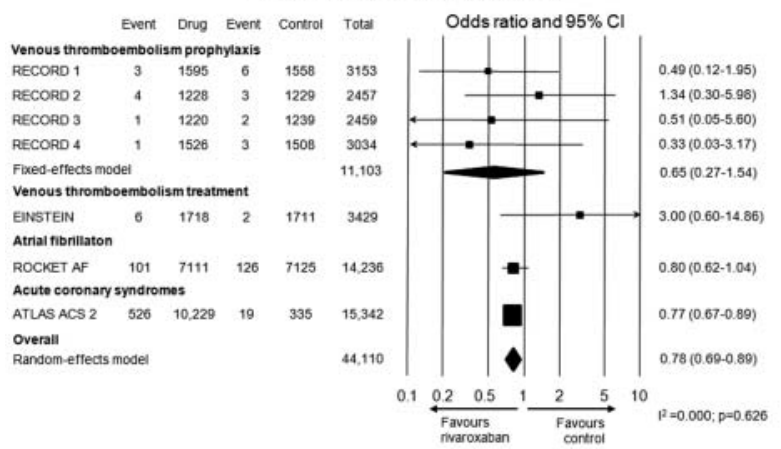

Apixaban: Coronary Events

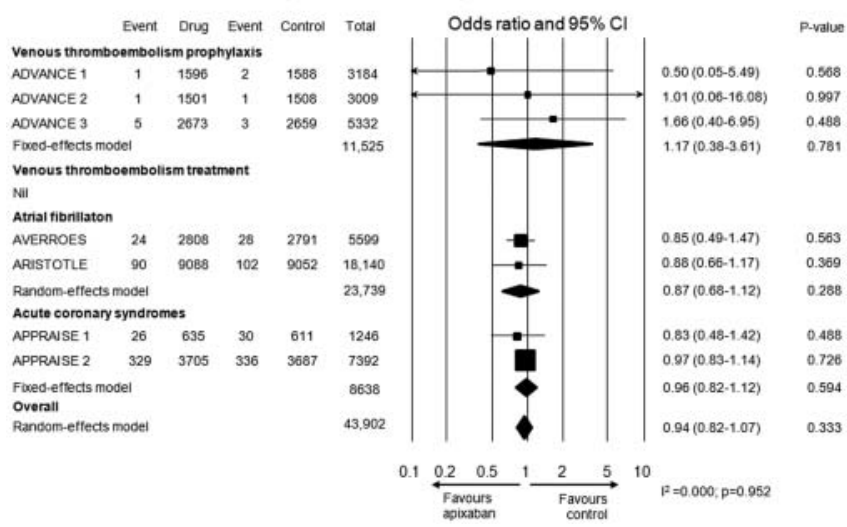

Figure 2 Risk of coronary events.

and knee replacement surgery ${ }^{37}$ and reduces tissue factor induced platelet aggregation. ${ }^{38}$ In vitro studies indicated that direct thrombin inhibitors were associated
Ximelagatran: Major bleeding complication

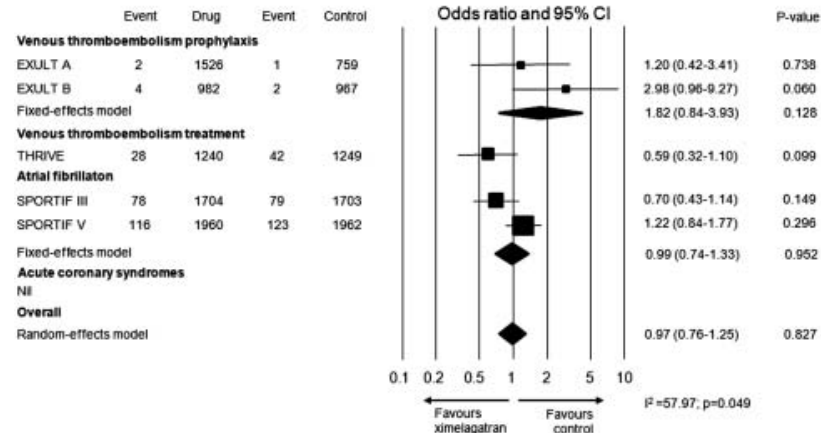

Dabigatran: Major bleeding complication

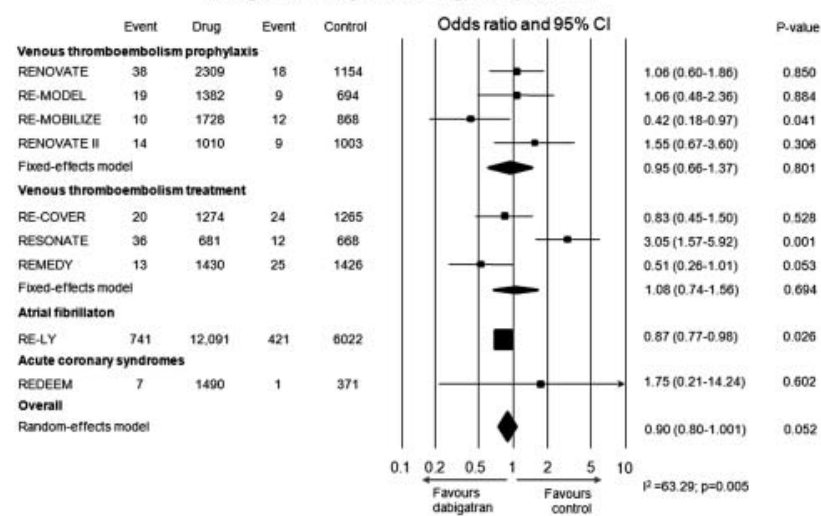

Rivaroxaban: Major bleeding complication

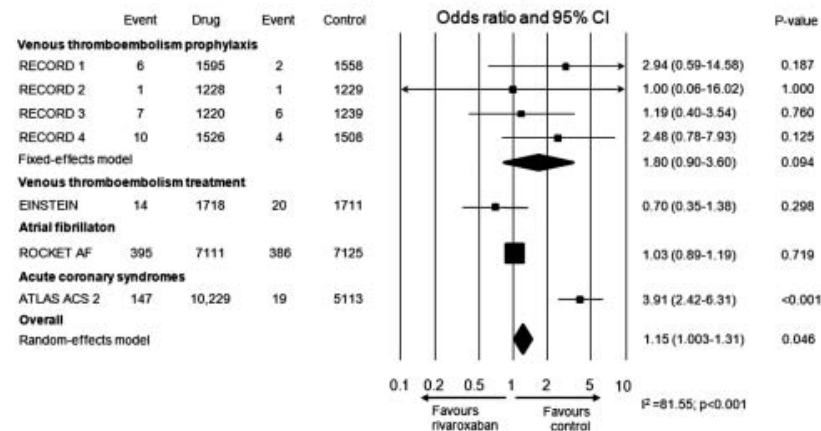

Apxiaban: Major bleeding complication

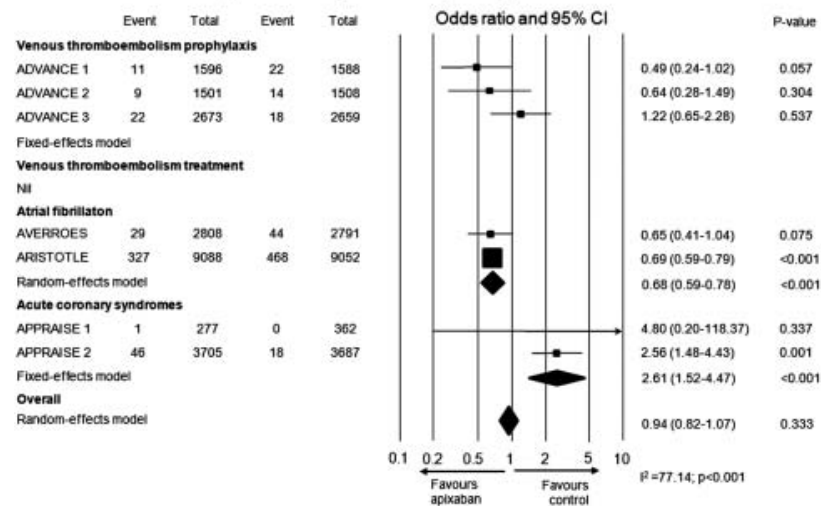

Figure 3 Risk for major bleeding complications.

with paradoxical coagulation compared with factor Xa inhibitors, ${ }^{39}$ which was likely mediated by preventing thrombin-induced activation of Protein C. This is a 
Ximelagatran: All-cause mortality

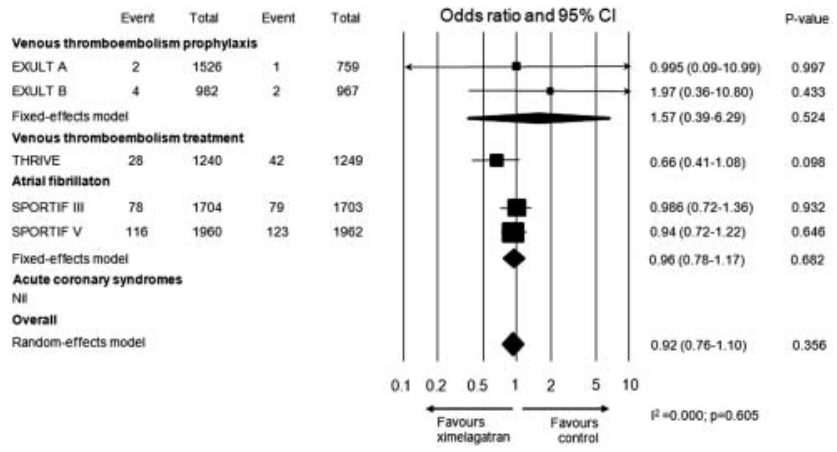

Dabigatran: All-cause mortality

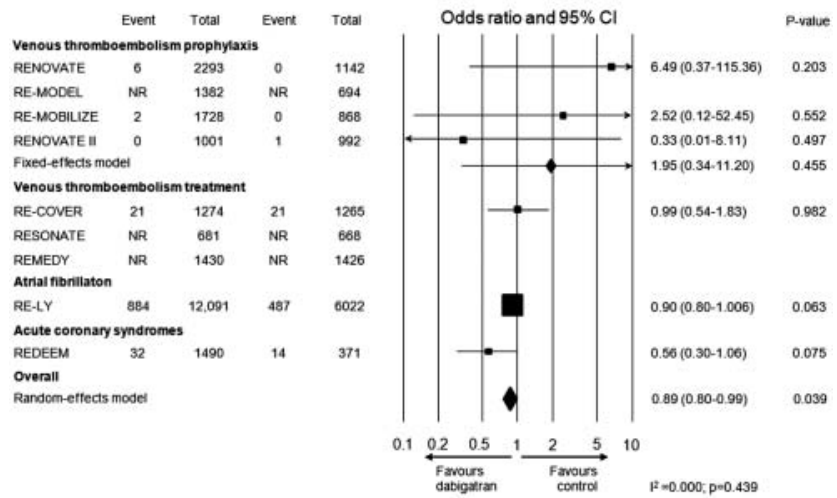

Rivaroxaban: All-cause mortality

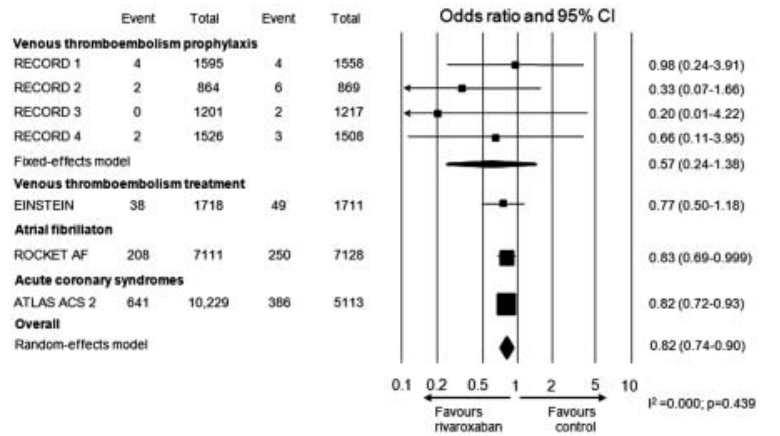

Apixaban: All-cause mortality

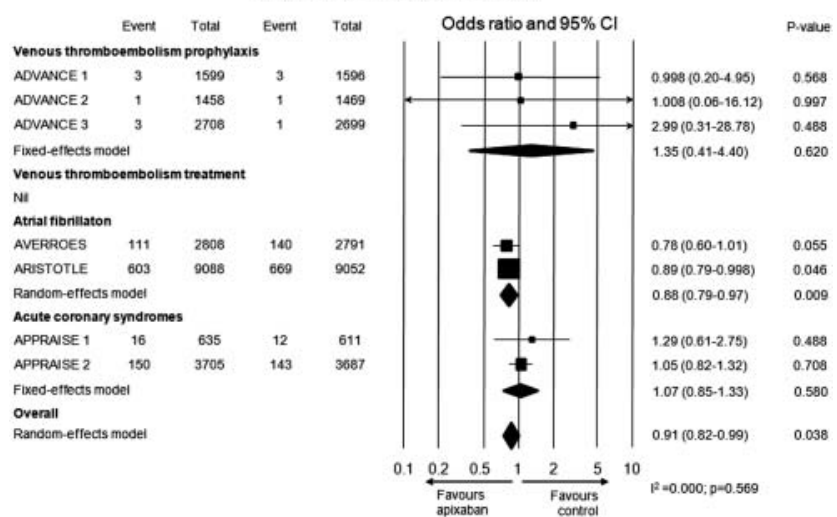

Figure 4 Risk for all-cause mortality.

natural anticoagulant and part of the negative feedback system after thrombin generation. Furthermore, inflammatory markers were increased with long-term use of
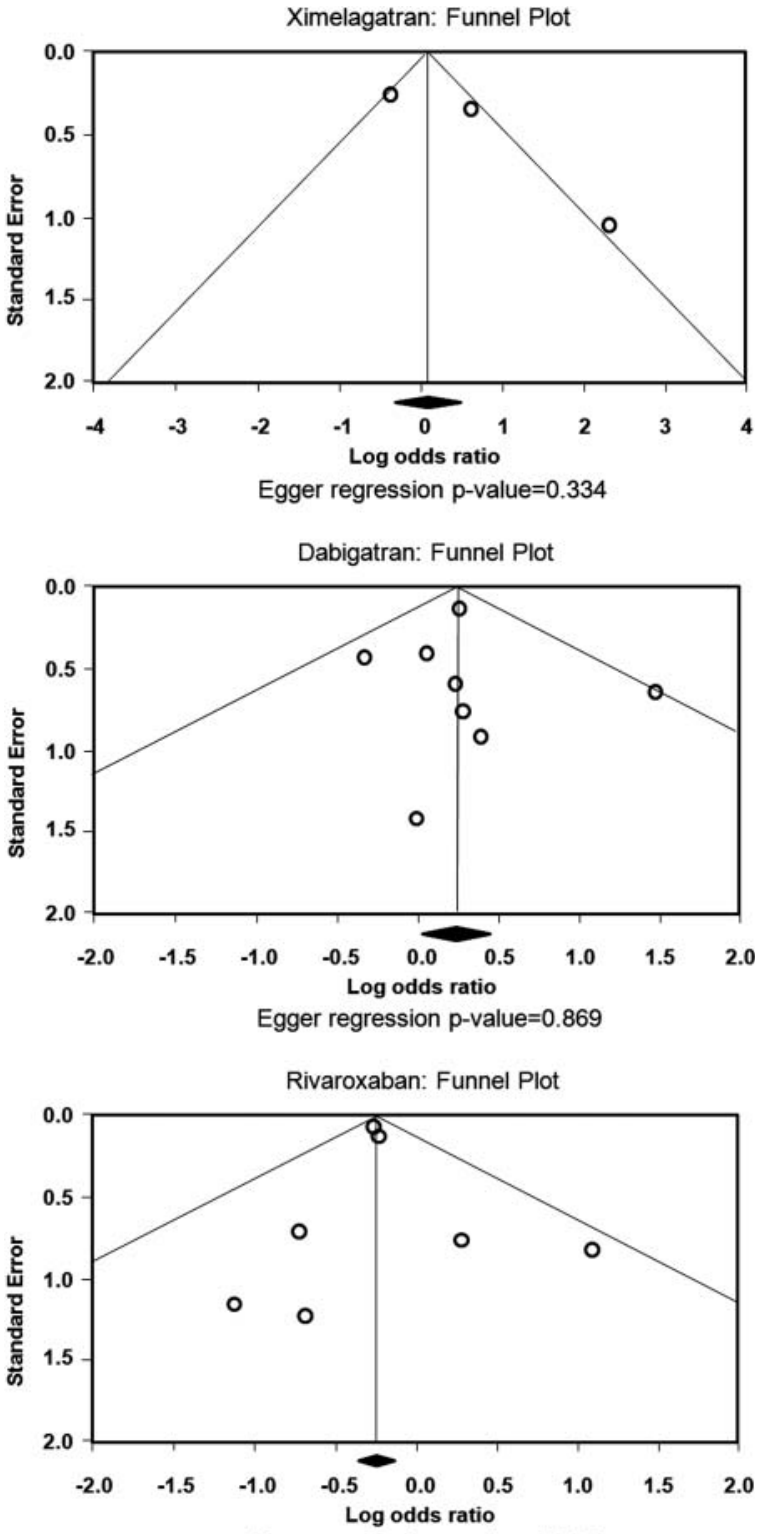

Egger regression p-value $=0.774$

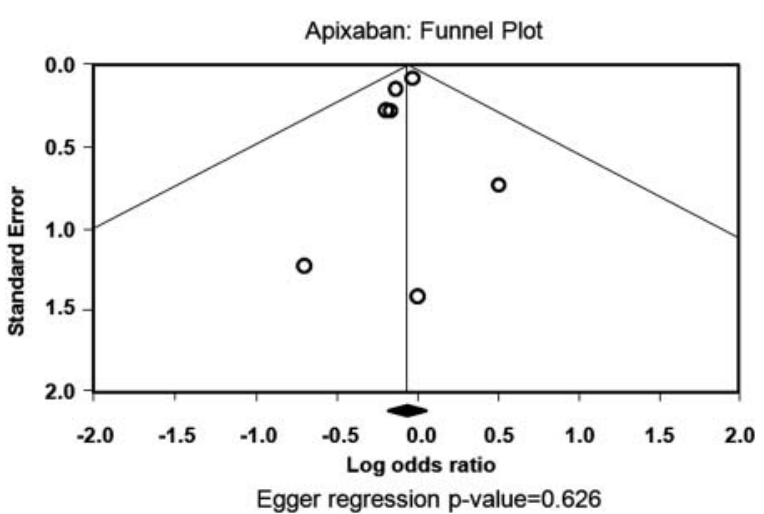

Figure 5 Fixed-effects funnel plot with Engger regression test for the evaluation of publication bias for coronary events.

direct oral thrombin inhibitors. ${ }^{40}$ Urinary 11-dehydrothromboxane $\beta 2$ was elevated for those receiving dabigatran compared with warfarin among 502 
Table 2 Definition of major bleeding complication and use of antiplatelet agents

\begin{tabular}{|c|c|}
\hline Study name & Major bleeding complication definition \\
\hline \multicolumn{2}{|c|}{ Venous thromboembolism prophylaxis } \\
\hline \multirow[t]{5}{*}{ EXULT A ${ }^{7}$} & Occurrence of at least one of the following: \\
\hline & 1. Critical site (intracranial, retroperitoneal, intraocular, intraspinal, pericardial) \\
\hline & $\begin{array}{l}\text { 2. Bleeding index } \geq 2.0 \text { (difference between baseline and postbleeding } \\
\text { haemoglobin level }(\mathrm{g} / \mathrm{l}) \text { plus number of packed cells or whole blood } \\
\text { transfusion }\end{array}$ \\
\hline & 3. Need for medical or surgical intervention at operative site \\
\hline & 4. Fatal \\
\hline EXULT B $^{8}$ & Not clearly stated \\
\hline RE-NOVATE ${ }^{9}$ & Acute overt clinical bleeding with one of the following: \\
\hline
\end{tabular}

\section{Antiplatelet agent}

Not allowed

1. Critical site (intracranial, retroperitoneal, intraocular, intraspinal, pericardial)

2. Fall in haemoglobin $\geq 20 \mathrm{~g} / \mathrm{l}$ in excess of that expected by investigator

3. Transfusion $\geq 2$ units of packed cells or whole blood in excess of that expected by investigator

4. Leading to re-operation

5. Warranting treatment cessation

6. Fatal

RE-MODEL ${ }^{10}$ As in RE-NOVATE

RE-MOBILIZE ${ }^{11}$ Occurrence of at least one of the following:

1. Symptomatic intracranial, retroperitoneal, intraocular or intraspinal bleeding

2. Clinically overt bleeding with fall of haemoglobin $\geq 2.0 \mathrm{~g} / \mathrm{dl}$ and/or leading to transfusion of $\geq 2$ units of packed cells or whole blood

3. Need for treatment cessation or surgical intervention at operative site

4. Fatal

RE-NOVATE $\|^{12}$ As in RE-NOVATE

RECORD $1^{13}$ Occurrence of at least one of the following:

1. Intracranial, retroperitoneal, intraocular or intraspinal bleeding

2. Clinically overt bleeding with fall of haemoglobin $\geq 2.0 \mathrm{~g} / \mathrm{dl}$

3. Transfusion of $\geq 2$ units of packed cells or whole blood

4. Need for surgical intervention at operative or bleeding site

5. Fatal

RECORD2 ${ }^{14}$ Occurrence of at least one of the following:

1. Critical site bleeding; for example, intracranial, retroperitoneal, intraocular or intraspinal

2. Clinically overt bleeding with fall of haemoglobin $\geq 2.0 \mathrm{~g} / \mathrm{dl}$ (calculated from first post-operative level)

3. Transfusion of $\geq 2$ units of packed cells or whole blood

4. Need for surgical intervention at operative or bleeding site

5. Fatal

RECORD $3^{15}$ Occurrence of at least one of the following:

1. Critical organ bleeding

2. Clinically overt bleeding with fall of haemoglobin $\geq 2.0 \mathrm{~g} / \mathrm{dl}$

3. Transfusion of $\geq 2$ units of packed cells or whole blood

4. Need for reoperation

5. Fatal

RECORD4 ${ }^{16} \quad$ Clinically overt bleeding:

1. In critical organ; for example, intracranial, retroperitoneal, intraocular or intraspinal

2. Fall of haemoglobin $\geq 2.0 \mathrm{~g} / \mathrm{dl}$ (calculated from postoperative level)

3. Transfusion of $\geq 2$ units of blood

4. Need for operation

5. Fatal

ADVANCE $1^{17}$ Acute overt clinical bleeding with one of the following:

1. Critical site (intracranial, retroperitoneal, intraocular, intraspinal, pericardial)

Not allowed

Aspirin dose $<162 \mathrm{mg}$ daily permitted

Aspirin dose $<160 \mathrm{mg}$ daily permitted

Aspirin dose $<160 \mathrm{mg}$

daily permitted

Aspirin dose $<162 \mathrm{mg}$

daily permitted

Not mentioned

Not mentioned

2. Fall in haemoglobin $\geq 2 \mathrm{~g} / \mathrm{dl}$ within $24 \mathrm{~h}$

3. Transfusion $\geq 2$ units of packed cells

not mentioned

not mentioned

not allowed 
Table 2 Continued

\begin{tabular}{|c|c|c|}
\hline Study name & Major bleeding complication definition & Antiplatelet agent \\
\hline & 4. Need for surgical intervention at operative site & \\
\hline & 5. Intramuscular bleeding with compartment syndrome & \\
\hline & 6. Fatal & \\
\hline ADVANCE $2^{18}$ & As in ADVANCE 1 & Not allowed \\
\hline ADVANCE $3^{19}$ & As in ADVANCE 1 & Not allowed \\
\hline \multicolumn{3}{|c|}{ Treatment of venous thromboembolism } \\
\hline \multirow[t]{5}{*}{ THRIVE ${ }^{20}$} & Clinically overt bleeding: & Aspirin at lowest \\
\hline & 1. In critical sites & effective dose \\
\hline & 2. Fall of haemoglobin $\geq 2.0 \mathrm{~g} / \mathrm{dl}$ & permitted \\
\hline & 3. Transfusion of $\geq 2$ units of blood or packed cells & \\
\hline & 4. Fatal & \\
\hline \multirow[t]{5}{*}{ RE-COVER ${ }^{21}$} & Clinically overt bleeding: & Aspirin $\leq 100 \mathrm{mg}$ daily \\
\hline & 1. In critical sites & permitted \\
\hline & 2. Fall of haemoglobin $\geq 20 \mathrm{~g} / \mathrm{l}$ & \\
\hline & 3. Transfusion of $\geq 2$ units of blood or packed cells & \\
\hline & 4. Fatal & \\
\hline RE-SONATE 22 & Not stated & Not stated \\
\hline REMEDY ${ }^{23}$ & Not stated & Not stated \\
\hline \multirow[t]{5}{*}{ EINSTEIN ${ }^{24}$} & Clinically overt bleeding: & Aspirin $\leq 100 \mathrm{mg}$ daily \\
\hline & 1. In critical sites; for example, intracranial and retroperitoneal & or clopidogrel $75 \mathrm{mg}$ \\
\hline & 2. Fall of haemoglobin $\geq 20 \mathrm{~g} / \mathrm{l}$ & daily, or both, were \\
\hline & 3. Transfusion of $\geq 2$ units of blood or packed cells & permitted \\
\hline & 4. Fatal & \\
\hline \multicolumn{3}{|c|}{ Prevention of embolic events in atrial fibrillation } \\
\hline \multirow[t]{5}{*}{ SPORTIF III 25} & Occurrence of at least one of the following: & Aspirin $\leq 100 \mathrm{mg}$ \\
\hline & $\begin{array}{l}\text { 1. Intracranial, retroperitoneal, intraocular, intraspinal, pericardial or atraumatic } \\
\text { intra-articular bleeding }\end{array}$ & daily permitted $(21 \%)^{*}$ \\
\hline & 2. Clinically overt bleeding with fall of haemoglobin $\geq 20 \mathrm{~g} / \mathrm{l}$ & \\
\hline & 3. Transfusion of $\geq 2$ units of erythrocytes or whole blood & \\
\hline & 4. Fatal & \\
\hline SPORTIF V 26 & As in SPORTIF III & $\begin{array}{l}\text { As in SPORTIF III } \\
(18 \%)^{*}\end{array}$ \\
\hline \multirow[t]{6}{*}{$\mathrm{RE}-L Y^{27}$} & Occurrence of at least one of the following: & Aspirin $<100 \mathrm{mg}$ daily \\
\hline & 1. Critical area or organ bleeding; for example, intracranial & or antiplatelet agent \\
\hline & 2. Clinically overt bleeding with fall of haemoglobin $\geq 20 \mathrm{~g} / \mathrm{l}$ & permitted $(40 \%)^{*}$ \\
\hline & 3. Transfusion of $\geq 2$ units of blood & \\
\hline & 4. Need for surgery & \\
\hline & 5. Fatal & \\
\hline \multirow[t]{6}{*}{ ROCKET AF ${ }^{28}$} & Clinically overt bleeding: & Aspirin $\leq 100 \mathrm{mg}$ daily \\
\hline & $\begin{array}{l}\text { 1. In critical anatomic site; for example, intracranial, retroperitoneal, ocular, } \\
\text { spinal, pericardial articular or intramuscular with compartment syndrome }\end{array}$ & $\begin{array}{l}\text { or monothienpyridine } \\
\text { therapy permitted }\end{array}$ \\
\hline & 2. Fall of haemoglobin $\geq 2.0 \mathrm{~g} / \mathrm{dl}$ & $(38.5 \%)^{\star}$ \\
\hline & 3. Transfusion of $\geq 2$ units of whole blood or packed cells & \\
\hline & 4. Permanent disability & \\
\hline & 5. Fatal & \\
\hline \multirow[t]{5}{*}{ AVERROES ${ }^{29}$} & Clinically overt bleeding: & Thienopyridine therapy \\
\hline & $\begin{array}{l}\text { 1. In critical sites; for example, intracranial, retroperitoneal, ocular, spinal, } \\
\text { pericardial, articular or intramuscular with compartment syndrome }\end{array}$ & permitted if needed \\
\hline & 2. Fall of haemoglobin $\geq 2.0 \mathrm{~g} / \mathrm{dl}$ & \\
\hline & 3. Transfusion of $\geq 2$ units of packed cells & \\
\hline & 4. Fatal & \\
\hline \multirow[t]{4}{*}{ ARISTOTLE ${ }^{30}$} & Clinically overt bleeding: & Aspirin $\leq 165 \mathrm{mg}$ daily \\
\hline & 1. In critical sites & or monothienopyridine \\
\hline & 2. Fall of haemoglobin $\geq 2.0 \mathrm{~g} / \mathrm{dl}$ over a $24 \mathrm{~h}$ period & permitted $(32 \%)^{*}$ \\
\hline & 3. Transfusion of $\geq 2$ units of packed cells & \\
\hline & & Continued \\
\hline
\end{tabular}


Table 2 Continued

\begin{tabular}{|c|c|c|}
\hline Study name & Major bleeding complication definition & Antiplatelet agent \\
\hline \multicolumn{3}{|c|}{ Treatment of acute coronary syndrome } \\
\hline RE-DEEM ${ }^{31}$ & $\begin{array}{l}\text { Occurrence of one of the following: } \\
\text { 1. Bleeding in critical sites; for example, intracranial, retroperitoneal, ocular, } \\
\text { spinal, pericardial, articular or intramuscular with compartment syndrome } \\
\text { 2. Fall of haemoglobin } \geq 2.0 \mathrm{~g} / \mathrm{dl} \\
\text { 3. Transfusion of } \geq 2 \text { units of packed cells or whole blood } \\
\text { 4. Fatal }\end{array}$ & $\begin{array}{l}\text { All patients receiving } \\
\text { dual antiplatelet agents }\end{array}$ \\
\hline ATLAS ACS 2 & Occurrence of one of the following: & All patients received \\
\hline TIMI $51^{32}$ & $\begin{array}{l}\text { 1. Fall of haemoglobin } \geq 5.0 \mathrm{~g} / \mathrm{dl} \text { or haematocrit }>15 \% \\
\text { 2. Intracranial haemorrhage }\end{array}$ & $\begin{array}{l}\text { low-dose aspirin and } \\
\text { thienopyridine permitted }\end{array}$ \\
\hline APPRAISE $^{33}$ & $\begin{array}{l}\text { Occurrence of one of the following: } \\
\text { 1. Bleeding in critical sites; for example, intracranial, retroperitoneal, ocular, } \\
\text { spinal, pericardial, articular or intramuscular with compartment syndrome } \\
\text { 2. Fall of haemoglobin } \geq 2.0 \mathrm{~g} / \mathrm{dl} \\
\text { 3. Transfusion of } \geq 2 \text { units of packed cells or whole blood } \\
\text { 4. Fatal }\end{array}$ & $\begin{array}{l}\text { All patients received } \\
\text { aspirin } \leq 165 \mathrm{mg} \text { daily } \\
\text { and thienopyridine } \\
\text { therapy permitted }\end{array}$ \\
\hline APPRAISE $2^{34}$ & $\begin{array}{l}\text { Occurrence of one of the following: } \\
\text { 1. Fall of haemoglobin } \geq 5.0 \mathrm{~g} / \mathrm{dl} \text { or haematocrit }>15 \% \\
\text { 2. Intracranial haemorrhage }\end{array}$ & $\begin{array}{l}\text { Use of aspirin and } \\
\text { thienopyridine } \\
\text { permitted }\end{array}$ \\
\hline
\end{tabular}

patients with atrial fibrillation and not treated with aspirin. ${ }^{41}$ But the preliminary results from a substudy of the RE-LY trial did not show this relationship. ${ }^{42}$ Nonetheless, taken together, the differences in thrombotic, inflammatory and platelet pathways could have accounted for some of the differences in coronary events. Furthermore, there was discordance in the main findings of SPORTIF III $^{25}$ and SPORTIF V. ${ }^{26}$ Although both studies were similar in design, there were important dissimilarities. SPORTIF III $^{25}$ was conducted in Europe, Asia plus Australasia and SPORTIF V ${ }^{26}$ was performed in North America. The design of the latter study $^{26}$ was double-blind but SPORTIF III was an openlabel trial. ${ }^{25}$ Of note, the primary endpoint, consisting of stroke and systemic embolism, was $2.3 \%$ per year for the warfarin group and $1.6 \%$ per year for the ximelagatran group in SPORTIF III. ${ }^{25}$ Conversely, it was $1.2 \%$ per year for the warfarin group and $1.6 \%$ per year for the ximelagatran group in SPORTIF $\mathrm{V}^{26}$ There were also differences in the occurrence of major bleeding complications (figure $3 \mathrm{~A}$ ). The authors attributed the differences to better dose regulation, control of hypertension or hyperlipidaemia, other differences in patient characteristics or management or chance. ${ }^{26}$

Evaluation for a summarised risk for major bleeding complications among these studies has been challenging because of the marked variation in study protocol and endpoint definition (table 2). Although there was little difference in major bleeding complications for the four agents when compared with control, the rates were higher for rivaroxaban ${ }^{32}$ and $\operatorname{apixaban}^{33} 34$ in ACS patients, and influenced this outcome. Likely, several of these patients were receiving antiplatelet therapy, and probably treated with these two agents.
Indeed, major bleeding complication rates have been noted to increase by $40-70 \%$ among those receiving aspirin plus clopidogrel in the RE-LY trial. ${ }^{43}$ Majority of these ACS patients were receiving dual antiplatelet agents. Not surprisingly, when these trials were excluded from analysis, evidence for heterogeneity was lost. Therefore, extreme caution has to be exercised when considering combining antiplatelet and antithrombotic agents because of the high bleeding risk.

Despite differences in the risks for MI/ACS and major bleeding complications, all-cause mortality was lower among those treated with dabigatran, rivaroxabn and apixaban compared with control. Better survival was also observed among patients with ACS treated with oral anticoagulation. All-cause and vascular mortalities were significantly lower among those receiving moderate intensity of warfarin plus aspirin compared to aspirin alone. ${ }^{44}$ Part of the reason for lower mortality for patients treated with novel antithrombotic agents may be related to the lower rates of haemorrhagic stroke for those with atrial fibrillation. $^{27} 28{ }^{30}$ If this finding is real then it may supersede the shortfalls of these agents such as lack of antidote for reversal of effects and assay to determine its therapeutic efficacy.

There are several limitations in the study. Importantly, there were differences in study population, protocol and procedures. Duration of follow-up varied considerably across trials. Individual patient outcome information was also not available. Definitions of outcome measures varied considerably in the studies and there were subjective elements in adjudication, especially for bleeding complications. Furthermore, not all the outcomes were reported in every trial. Silent MI 
may be actively sought out for in some studies, especially after revascularisation procedures, with routine electrocardiography or cardiac enzyme assays. But this approach may not be adopted in other trials. While this difference could have accounted for variation observed among studies, it was less likely to impact on the results within a study. Another limitation was that there was only one author in the study; there may be potential bias in study appraisal and selection stages. However, this concern is mitigated somewhat by relatively small total number of trials and fairly well-defined outcome measures. Nonetheless, these findings were instructive in providing insight on the relative occurrence adverse cardiovascular events impacting on the choice of these agents in specific patient subsets requiring anticoagulation. As with any results from meta-analyses, a firm conclusion can only be drawn from well-conducted, adequately powered randomised trials.

Competing interests None.

Provenance and peer review Not commissioned; externally peer reviewed.

Data sharing statement There are no additional data available.

\section{REFERENCES}

1. Connolly SJ, Ezekowitz MD, Yusuf S, et al. Dabigatran versus warfarin in patients with atrial fibrillation. $N$ Engl J Med 2009;361:1139-51.

2. Hohnloser SH, Oldgren J, Yang S, et al. Myocardial ischemic events in patients with atrial fibrillation treated with dabigatran or warfarin in the RE-LY (Randomized Evaulation of Long-Term Anticoagulation Therapy) Trial. Circulation 2012;125:669-76.

3. Uchino K, Hernandez AV . Dabigatran association with higher risk of acute coronary events. Meta-analysis of nononferiority randomized controlled trials. Arch Intern Med 2012;172:372-402.

4. Jadad AR, Moore RA, Carroll D, et al. Assessing the quality of reports of randomized clinical trials: is blinding necessary? Controlled Clin Trials 1996;17:1-12.

5. Higgins JP, Thompson SG. Quantifying heterogeneity in a meta-analysis. Stat Med 2002;21:1539-58.

6. Egger M, Davey Smith G, Schneider M, et al. Bias in meta-analysis detected by a simple, graphical test. Br Med J 1997;315:1559-73.

7. Francis CW, Berkowitz SD, Comp PC, et al. Comparison of ximelagatran with warfarin for the prevention of venous thromboembolism after total knee replacement. $N$ Engl J Med 2003;349:1703-12

8. Colwell CW Jr, Berkowitz SC, Lieberman JR, et al. Oral direct thrombin inhibitor ximelagatran compared with warfarin for the prevention of venous thromboembolism after total knee arthroplasty. J Bone Joint Surg Am 2005;87:2169-77.

9. Eriksson BI, Dahl OE, Rosencher N, et al. Dabigatran etexilate versus enoxaparin for prevention of venous thromboembolism after total hip replacement: a randomised, double-blind, non-inferiority trial. Lancet 2007;370:949-56.

10. Eriksson $\mathrm{BI}$, Dahl OE, Rosencher $\mathrm{N}$, et al. Oral dabigatran etexilate vs. subcutaneous enoxaparin for the prevention of venous thromboembolism after total knee replacement: the RE-MODEL randomized trial. J Thromb Haemost 2007;5:2178-85.

11. The RE-MOBILIZE Writing Committee. Oral thrombin inhibitor dabigatran etexilate vs North American enoxaparin regimen for prevention of venous thromboembolism after knee arthroplasty surgery. J Arthroplasty 2009;24:1-9.

12. Eriksson $\mathrm{BI}$, Dahl OE, Huo $\mathrm{MH}$, et al. Oral dabigatran versus enoxaparin for thromboprophylaxis after primary total hip arthroplasty (RE-NOVATE II). Thromb Haemost 2011;105:721-9.

13. Eriksson BI, Borris LC, Friedman RJ, et al. Rivaroxaban versus enoxaparin for thromboprophylaxis after hip arthroplasty. $N$ Engl J Med 2008;358:2765-75.

14. Kakkar AK, Brenner B, Dahl OE, et al. Extended duration rivaroxaban versus short-term enoxaparin for the prevention of venous thromboembolism after total hip arthroplasty: a double-blind, randomised controlled trial. Lancet 2008;372:31-19.

15. Lassen MR, Ageno W, Borris LC, et al. Rivaroxaban versus enoxaparin for thromboprophylaxis after total knee arthroplasty. $N$ Engl J Med 2008;358:2776-86.

16. Turpie AGG, Lassen MR, Davidson BL, et al. Rivaroxaban versus enoxaparin for thromboprophylaxis after total knee arthroplasty (RECRORD4): a randomised trial. Lancet 2009;373:1673-80.

17. Lassen MR, Raskob GE, Gallus A, et al. Apixaban or enoxaparin for thromboprophylaxis after knee replacement. $N$ Engl J Med 2009;361:594-604.

18. Lassen MR, Raskob GE, Gallus A, et al. Apixaban versus enoxaparin for thromboprophylaxis after knee replacement (ADVANCE-2): a randomised double-blind trial. Lancet 2010;375:807-15.

19. Lassen MR, Gallus A, Raskob GE, et al. Apixaban versus enoxaparin for thromboprophylaxis after hip replacement. $N$ Engl $J$ Med 2010;363:2487-98.

20. Fiessinger J-N, Huisman MV, Davidson BL, et al. Ximelagatran vs low-molecular-weight heparin and warfarin for the treatment of deep vein thrombosis: a randomized trial. JAMA 2005;293:681-9.

21. Schulman $S$, Kearon $C$, Kakkar AK, et al. Dabigatran versus warfarin in the treatment of acute venous thromboembolism. $N$ Engl J Med 2009;361:2342-52.

22. Schulman $\mathrm{S}$, Baanstra $\mathrm{D}$, Eriksson $\mathrm{H}$, et al. Dabigatran versus placebo for extended maintenance therapy of venous thromboembolism (abstract). J Thromb Haemost 2011;9:22.

23. Schulman S, Eriksson H, Goldhaber SZ, et al. Dabigatran or warfarin for extended maintenance therapy of venous thromboembolism (abstract). J Thromb Haemost 2011;9:731.

24. The EINSTEIN Investigators. Oral rivaroxaban for symptomatic venous thromboembolism. N Engl J Med 2010;363:2499-510.

25. Executive Steering Committee on behalf of the SPORTIF III Investigators. Stroke prevention with the oral direct thrombin inhibitor ximelagatran compared with warfarin in patients with non-valvular atrial fibrillation (SPORTIF III): a randomised trial. Lance 2003;362:1691-8.

26. SPORTIF Executive Steering Committee for the SPORTIF V Investigators. Ximelagatran vs warfarin for stroke prevention in patients with nonvalvular atrial fibrillation: a randomized trial. JAMA 2005;293:690-8.

27. Connolly S, Ezekowitz M, Yusuf S, et al. Dabigatran versus warfarin in patients with atrial fibrillation. $N$ Engl J Med 2009;361:1139-51.

28. Patel MR, Mahaffey KW, Garg J, et al. Rivaroxaban versus warfarin in nonvalvular atrial fibrillation. $N$ Engl $\mathrm{J}$ Med 2011;365:883-91.

29. Connolly SJ, Eikelboom J, Joyner C, et al. Apixaban in patients with atrial fibrillation. N Engl J Med 2011;364:806-17.

30. Granger CB, Alexander JH, McMurray JJV, et al. Apixaban versus warfarin in patients with atrial fibrillation. $N$ Engl $J$ Med 2011;365:981-92.

31. Oldgren J, Budaj A, Granger CB, et al. Dabigatran vs. placebo in patients with acute coronary syndromes on dual antiplatelet therapy: a randomized, double-blind, phase II trial. Eur Heart $J$ 2011;32:2781-9.

32. Mega JL, Braunwald E, Wiviott SD, et al. Rivaroxaban in patients with a recent acute coronary syndrome. $N$ Engl J Med 2012;366:9-19.

33. APPRAISE Steering Committee and Investigators. Apixaban, an oral, direct, selective factor $\mathrm{Xa}$ inhibitor, in combination with antiplatelet therapy after acute coronary syndrome: results of the Apixaban for Prevention of Acute Ischemic and Safety Events (APPRAISE) Trial. Circulation 2009;119:2877-85.

34. Alexander $\mathrm{JH}$, Lopes $\mathrm{RD}$, James $\mathrm{S}$, et al. Apixaban with antiplatelet therapy after acute coronary syndrome. $N$ Engl $J$ Med 2011;365:699-708

35. Sarich TC, Wolzt M, Eriksson UG, et al. Effects of ximelagatran, an oral direct thrombin inhibitor, r-hirudin and enoxaparin on thrombin generation and platelet activation in healthy male subjects. $J \mathrm{Am}$ Coll Cardiol 2003;41:557-64.

36. Boström SL, Hansson GF, Kiaer M, et al. Effects of melagatran, the active form of the oral direct thrombin inhibitor ximelagatran, and dalteparin on the endogenous thrombin potential in venous blood from healthy male subjects. Blood Coagul Fibrinolysis 2003;14:457-62.

37. Green L, Lawrie AS, Patel S, et al. The impact of elective knee/ hip replacement surgery and thromboprophylaxis with rivaroxaban or dalteparin on thrombin generation. Br J Haematol 2010;15:469-76.

38. Perzbon R, Harwardt M, Heitmeier S, et al. The effect of the oral direct factor $\mathrm{Xa}$ inhibitor rivaroxaban on tissue factor mediated in 
vitro platelet aggregation is enhanced by a P2Y receptor block (abstract). J Thromb Haemost 2011;9:74.

39. Furugohri $\mathrm{T}$, Sugiyama $\mathrm{N}$, Morishima $\mathrm{Y}$, et al

Antithrombin-independent thrombin inhibitors, but not direct $\mathrm{Xa}$ inhibitors, enhance thrombin generation in plasma through inhibition of thrombin-thrombomodulin-protein C system. Thromb Haemost 2011;106:1076-83.

40. Christersson C, Oldgren J, Wallentin L, et al. Treatment with an oral direct thrombin inhibitor decreases platelet activity but increases markers of inflammation in patients with myocardial infarction. $J$ Intern Med 2011;270:215-23.

41. Ezekowitz MD, Reilly PA, Nehmiz G, et al. Dabigatran with and without concomitant aspirin compared with warfarin alone in patients with nonvalvular atrial fibrillation (PETRO Study). Am J Cardio 2007; 100:1419-26.
42. Eikelboom J, Oldgren J, Reilly $\mathrm{P}$, et al. No evidence of platelet activation in patients with atrial fibrillation who are treated with dabigatran: a substudy of the RELY Trial (abstract). J Thromb Haemost 2011;9:346.

43. Eikelboom JW, Wallentin L, Connolly SJ, et al. Risk of bleeding with 2 doses of dabigatran compared with warfarin in older and younger patients with atrial fibrillation. An analysis of the Randomized Evaulation of Long-Term Anticoagulation Therapy (RE-LY) Trial. Circulation 2011;123:2363-72.

44. van Es RF, Jonker JJC, Verheugt FWA, et al., for the Antithrombotics in the Secondary Prevention of Events in Coronary Thrombosis-2 (ASPECT-2) Research Group. Aspirin and coumadin after acute coronary syndromes (the ASPECT-2 study): a randomised controlled trial. Lancet 2002;360:109-13. 